УДК:725.82.04

ББК: $85.113(3)$

DOI: 10.18688/aa2111-06-55

P. Sanvito

\title{
Progress of Spatial Acoustics in the Northern Italian Theatres and Stage Architecture during the Baroque Era ${ }^{1}$
}

The state of the question - the results of the acoustical investigations carried out in the last years

Until a few years ago, the architectural history of the early modern era only sporadically addressed the problem of sound regulation and optimisation inside closed spaces (in the German speaking scholarly world: Raumakustik, a specific sector of this discipline).

Contrarily to the above-mentioned state of the arts, currently we are experiencing a flood of publications about some of the greatest European stage architects, such as Palladio, Scamozzi, or the Bibiena architectural dynasty: the first two being very established architects, to whom symposia and exhibitions have been dedicated. This publication flood was partially due to the recurrence of some anniversary dates: 500 years Palladio's birth in 1508; 400 after Scamozzi's treatise publication (1615), or 400 since his death (1616). Nevertheless, there have unfortunately been only isolated references to their views on the subject of theatre acoustics and very scarce research on their bequests in the field.

This is the reason why, for about a decade now and precisely in Germany, where some of Europe's leading acoustics researchers are based and where the most lively debates on concert halls have been taking place, some core questions needed to get resolutely addressed. First, at what level of acoustical skill the buildings of the ancient régime have been erected; and second, what are the ways in which good acoustics could be achieved in the architecture from the early modern period via the classical period (i.e. the time of Beethoven, or Haydn) and through the Romantic era.

Accordingly, I have been working for several years, together with numerous colleagues and members (primarily) of the Technical University of Berlin and some other universities, on the understanding of sophisticated acoustics in performance spaces. In particular, I have constantly been concerned with the standards of effective and proficient listening for the audiences of the early modern period ${ }^{2}$. The project "Acoustical Investigations of Theatrical Spaces in the Early Modern Era" was dedicated to specific modern case studies of performance spaces, first taking into account their sonic compatibility to our contemporary standards, and secondly their

\footnotetext{
1 I would like to thank my German colleagues Stefan Weinzierl and Frank Schultz for sharing the materials we have collected during the common project works.

2 Stefan Weinzierl (TU Berlin), Clemens Büttner, and Frank Schultz (Graz; formerly Berlin, Rostock).
} 
adaptability to the newer performance genres that did not emerge until 1550 (the early opera, the chamber opera, including of course the smaller or larger instrumental concert, the solo or the polyphonic singing - choirs, also a cappella , and the speaking voice of the recitative).

Of course, one can only limit oneself to the few still available and uncompromised architectural monuments: that is why an integral part of my work is a collation of the architecture possibly well preserved in an original state, and I have been attempting to compile the census of preserved buildings since the beginning of the research. Many baroque theatres, besides, are only known to us graphically, via a pretty good wealth of architectural drawings: a quantity of planning documents have been handed down from the $18^{\text {th }}$ century until today, but a great deal of all buildings have undergone a structural transformation, mostly in order to modernise or extend their stage capacity. Therefore, if they have survived to this day, they are usually no longer furnished with the $17^{\text {th }}$-century stage design.

The earliest preserved musical theatre, the Teatro Olimpico in Vicenza (Fig. 1), dates from 1585. The few earlier buildings used for a teatro di prosa or for a musical theatre, unfortunately no longer come into consideration due to their insufficient preservation or complete destruction (Vasarian Theatre, Palazzo Vecchio, Fig. 2). The following century, however, offered a wide range of well-preserved buildings, which constitute a stopover on the way to the classical opera house of the second half of the $18^{\text {th }}$ century: they were usually small, but often interestingly improved or rebuilt in the late baroque period. Jesuit scientists published on the subject from the middle of the century onward: Oswald Coscan, Mario Bettini and Giuseppe Zanchi ${ }^{3}$ among others (Fig. 3).

In the $18^{\text {th }}$ century, many architects, such as Enea Arnaldi or the Bibiena, were concerned with the improvement of technical as well as acoustical conditions. They also left some writings on the subject with a marked refinement of physical scientific devices or mechanisms: Arnaldi in 1762 sharply pointed to the tragic condition of traditional theatres, which often burned down to the ground, just like it happened in 1749 in Verona with the Filarmonico theatre, which in 1732 had just been perfectly completed by Francesco Galli Bibiena (Fig. 4). Arnaldi's proposals for reconstructions of modern theatres very much follow the same rationalising path propagated by the later Bibiena generations; for example, with the Mantuan Scientifico theatre by Antonio, the path also already experienced in the late renaissance by renowned theatre architects such as Scamozzi, in Sabbioneta (1590), or Aleotti, in Parma (1618) (Fig. 5) (with wide tiers or ranks, avoiding the superimposition of high wooden loge-constructions): these houses were even less constipated than our average large opera houses around Europe nowadays.

Bettini, M. \& Manzini, C. A. (1642) Apiaria vniversæ philosophiae mathematicae, in qvibus paradoxa, et noua pleraque machinamenta ad vsus eximios, traducta, \& facillimis demonstrationibus confirmata, illvstriss. Iesu dicata ... Accessit ad finem secvndi tomi Euclides applicatvs, et conditus et Apiarijs, indicatis vsibus eximijs præcipuarum propositionum in prioribus sex libris Euclideorum Elementarum. [Bononiæ: typis I. B. Ferronij, M. DC.XXXXII] [Image] Retrieved from the Library of Congress, https:/www.loc.gov/item/11005458/.

3 Coscan published in Ingolstad (1619), Bettini in Bologna (1642), and Zanchi in Vienna (1753). 


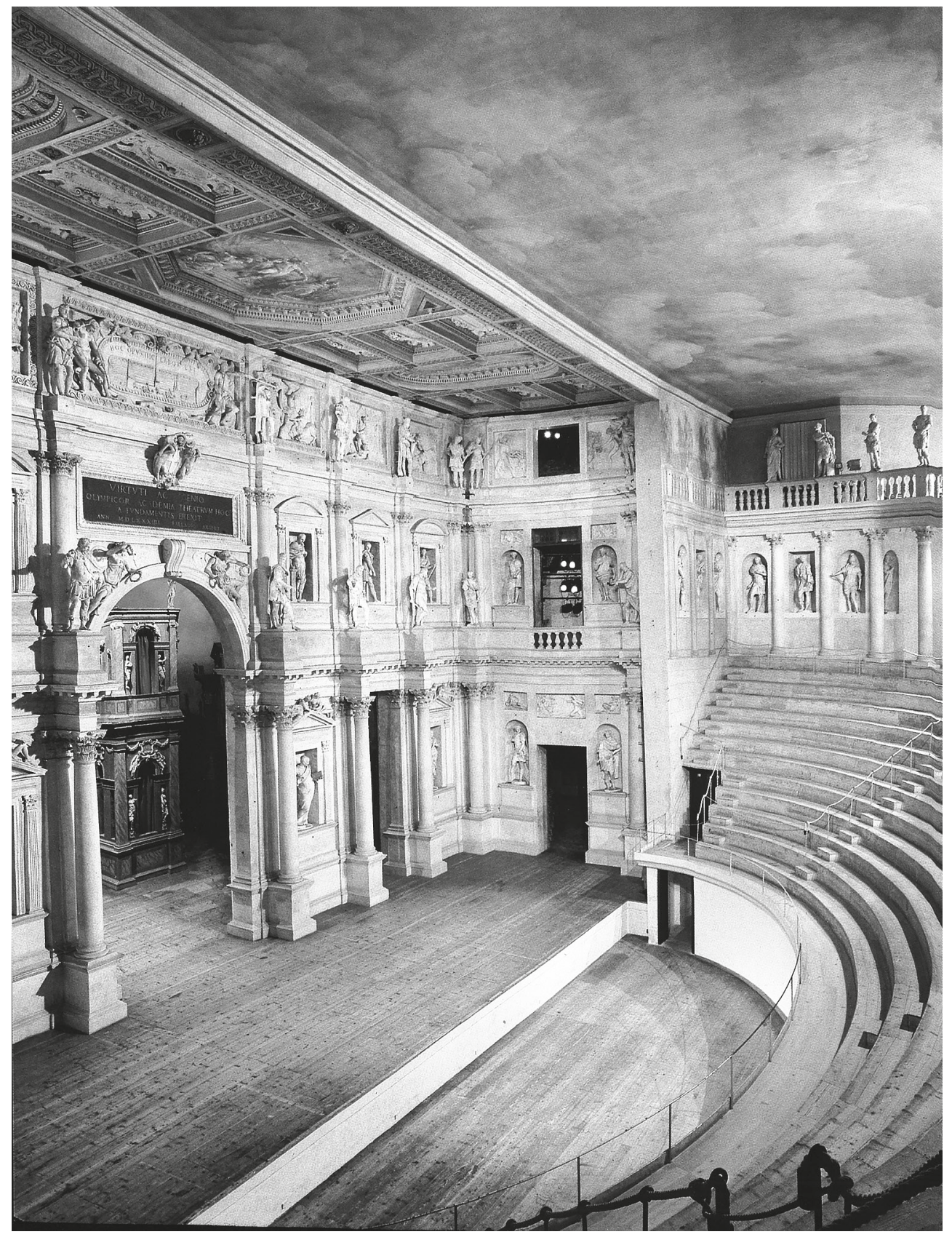

Fig. 1. Vicenza, Olimpico theatre, interior view toward the right versura, 1585. Photo by P. Sanvito 


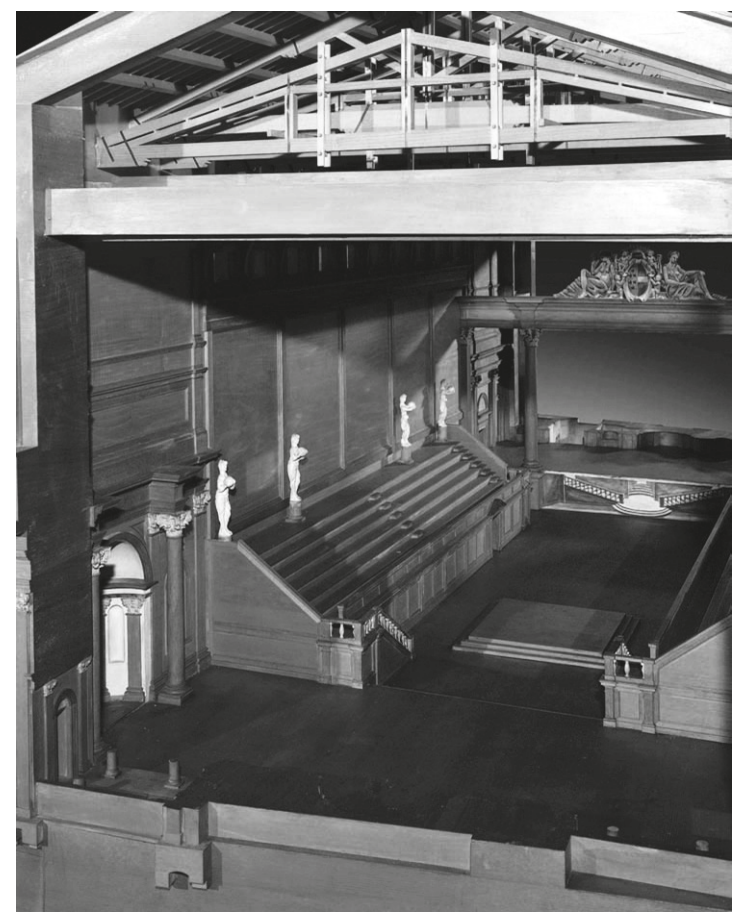

Fig. 2. Florence, Theatre of Palazzo Vecchio, formerly with a wooden structure by Giorgio Vasari, 1564. Model (scale 1:25) by Cesare Lisi, 1975. Wood, $252 \times 117 \times 124 \mathrm{~cm}$. Palazzo Medici Riccardi, Florence. Photo by P. Sanvito

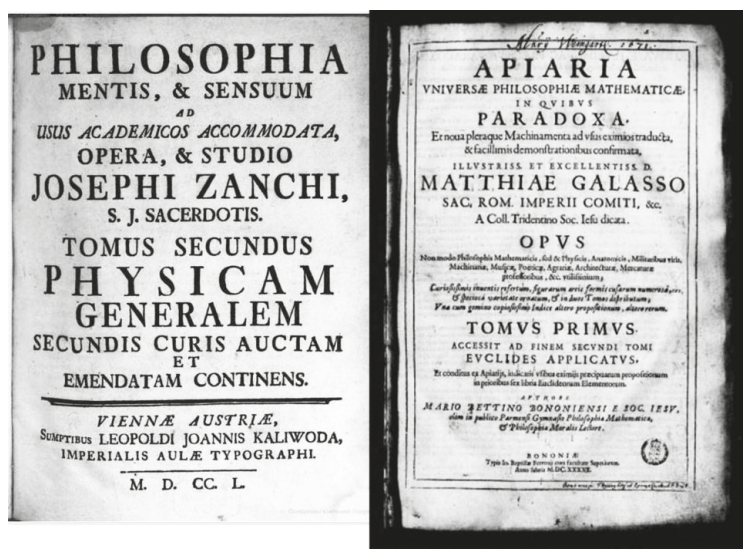

Fig. 3. Giuseppe Zanchi (1750) and Mario Bettini (1642), frontispieces. Zanchi G. Philosophia Mentis, \& Sensuum: Ad Usus Academicos Accommodata...Vienæ, MDCCL. [Image] Retrieved from the Bayer. Staatsbibliothek, https://books.google.com.ec/books?id=azM_ AAAAcAAJ\&printsec $=$ frontcover $\mathrm{v}=$ onepage $\& \mathrm{q} \& \mathrm{f}=$ false 


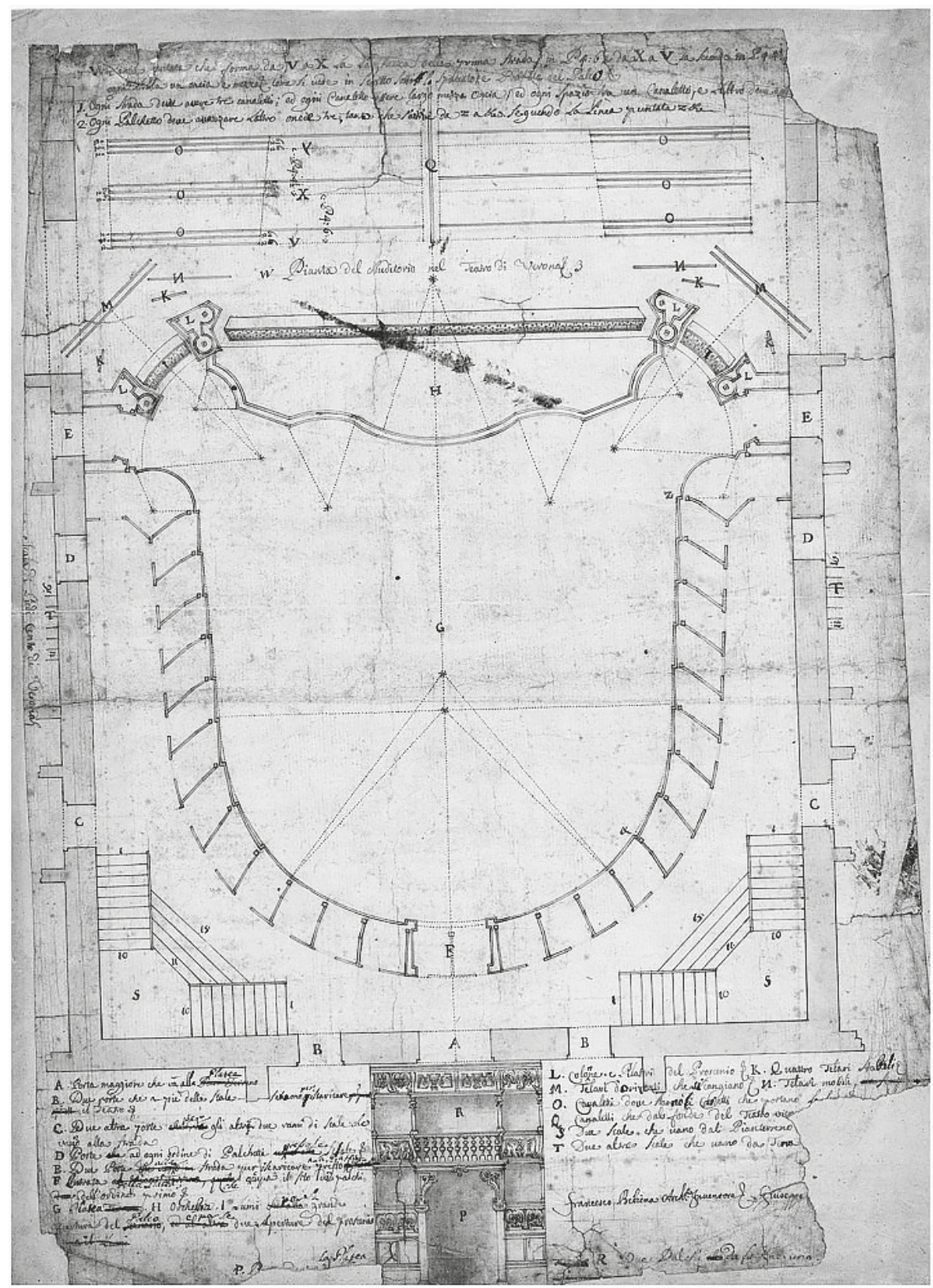

Fig. 4. Verona, Filarmonico Theatre, completed in 1732 by Francesco Galli Bibiena, early stage no more extant. Drawing by Jean-Joseph Chamant and after Francesco Galli Bibiena. dated 1715. Smithsonian Design Museum, Collection Cooper Hewitt. Available at: https:/upload.wikimedia.org/wikipedia/commons/1/16/Francesco_Galli_ Bibiena_-_Theatro_Filarmonico_of_the_Accademia_Filarmonica_of_Verona\%2C_Italy\%2C_Auditorium_and_ Main_Entrance_Elev..._-_Google_Art_Project.jpg 


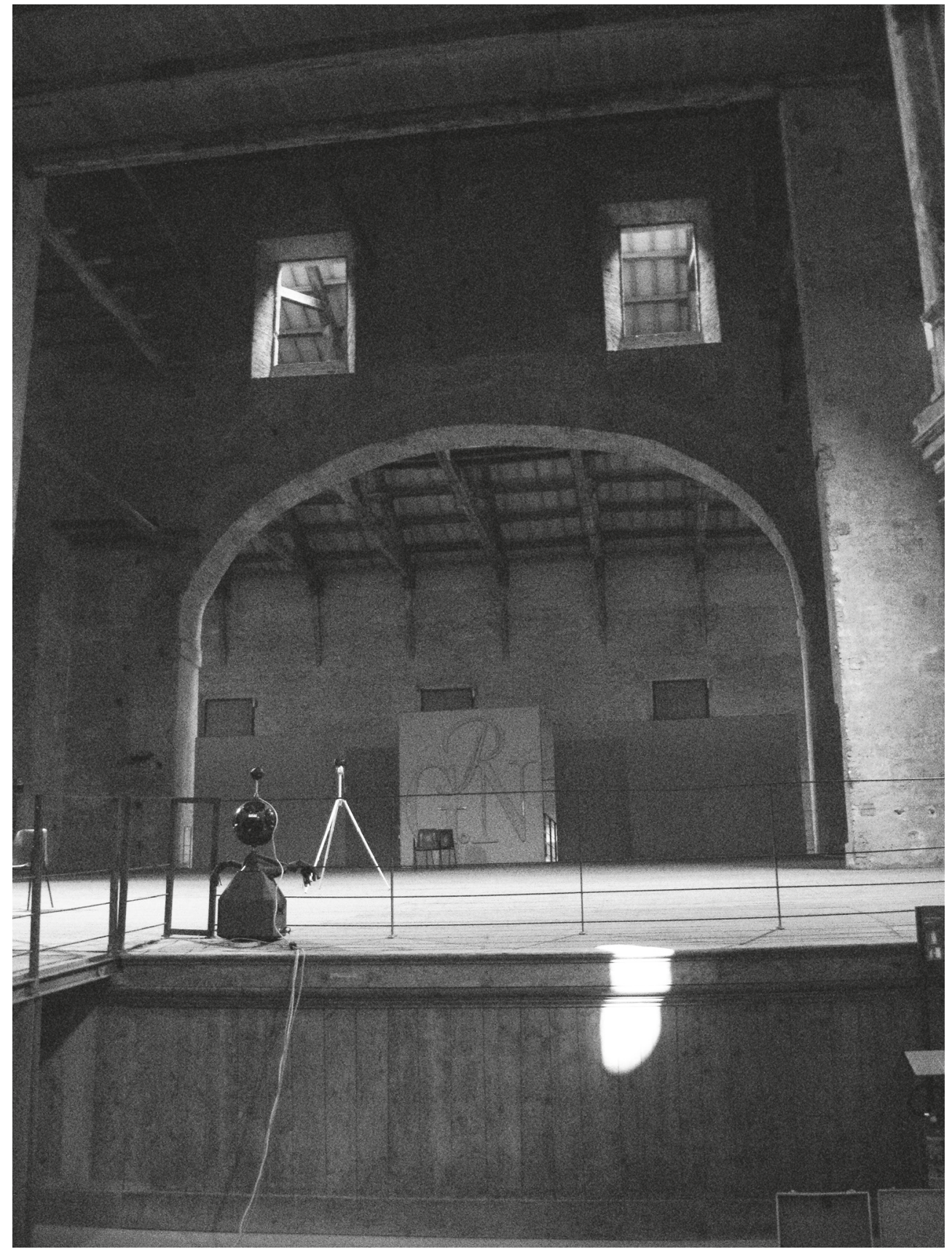

Fig. 5. Parma, Farnese Theatre, 1618, stage, with a 3-way dodecahedron speaker used for sending sound signals. Photo by P. Sanvito 
During the same historical turn of the mid- $18^{\text {th }}$ century in Italy, the discussion about the preservation of theatres was receiving an intensified attention, so that even a renowned architectural theoretician from Naples, Berardo Galiani, an expert of theatres from Antiquity, had to express himself on the Vicenza theatre and its restoration (Galiani, ideal Greek theatre, from his De architectura, traduzione italiana con testo latino a fronte e 25 rami dello stesso autore, Napoli, 1758, pl. XVII; his parere, 'expertise', is preserved in the Communal Archive in Padova as Memorie sull'Olimpico): Parere del Marchese Bernardo [sic] Galiani dato sulla copertura del Palco del teatro Olimpico di Vicenza written after request expressed by the Sig. Residente di Venezia in Napoli (Venetian ambassador), including, as the author specifies, "la descrizione [...] del Sig. Conte Enea Arnaldi contenente l'idea di un Teatro moderno a somiglianza dell'antico"4. It might be worthwhile remembering that even the residence of the mentioned ambassador in Naples was a palace with features in Palladian style, whose significant name was Palazzo Venezia. Private and public tastes were thus apparently uniformed in the Italian Peninsula.

The Berlin Department for Audio Communication and I have collected a rich wealth of measurement data as well as inventories and evaluated them step by step. The results obtained so far by the audio communication team have been met with interest within and beyond Europe. The relevance of the topic of theatre construction was recently reflected again at the Free University Berlin in a project inspired by ours ${ }^{5}$.

The subject of the investigations published from 2010 onwards within the project have been the following exemplary buildings in Italy, which we considered as pioneers for further investigations, especially the third one because of the long duration of its activity:

1) the Teatro Olimpico in Vicenza (1585);

2) the Teatro degli Antichi in Sabbioneta (1590);

3) the Teatro Farnese in Parma (1618), about which the edited measurements are still to be commented.

Besides, other measurements, some of them carried out in 2011, were taken in the following buildings; their results are archived in such a Protokoll (Protocol):

(Room acoustical measurements, Parma, Teatro Farnese)

„[...] 2011, $11^{\circ} \mathrm{C}$,

LS Bühne an der Bühnenkante, $1.5 \mathrm{~m}$ rechts von der Mitte

RIRs:
M0001_S01_R01
M0002_S01_R01
M0003_S01_R01
M0004_S01_R01
M0005_S01_R01
M0006_S01_R01

RIRs:

M0001_S01_R01

M0003 S01 R01

M0004_S01_R01

M0006_S01_R01

\begin{abstract}
Mic mittig in Orchestra, $15 \mathrm{~m}$ von der Bühnenkante (Beginn Zuschauerränge) Mic seitlich vor Brüstung, $15 \mathrm{~m}$ von der Bühnenkante (Beginn Zuschauerränge) Mic mittig in Orchestra, $25 \mathrm{~m}$ von der Bühnenkante Mic seitlich vor Brüstung, $25 \mathrm{~m}$ von der Bühnenkante Mic mittig hinter Brüstung, $37 \mathrm{~m}$ von der Bühnenkante Mic mittig, 1. Rundgang, 46m von der Bühnenkante
\end{abstract}

\footnotetext{
4 Padua, Biblioteca Comunale / Civica di Padova, Parere del Marchese Bernardo [sic] Galiani dato sulla copertura del Palco del teatro Olimpico di Vicenza [in esecuzione degli ordini avutine dal Sig. Residente di Venezia in Napoli], shelf mark BP2537/6, as we read in the first folio.

5 Among other publications see especially: [19]. In terms of medial resonance, see also the cultural Feuilleton of the newspaper Frankfurter Allgemeine Zeitung from September, 21, 2011, p. 3: „Der Nachhall macht des Sprechers Würde“.
} 


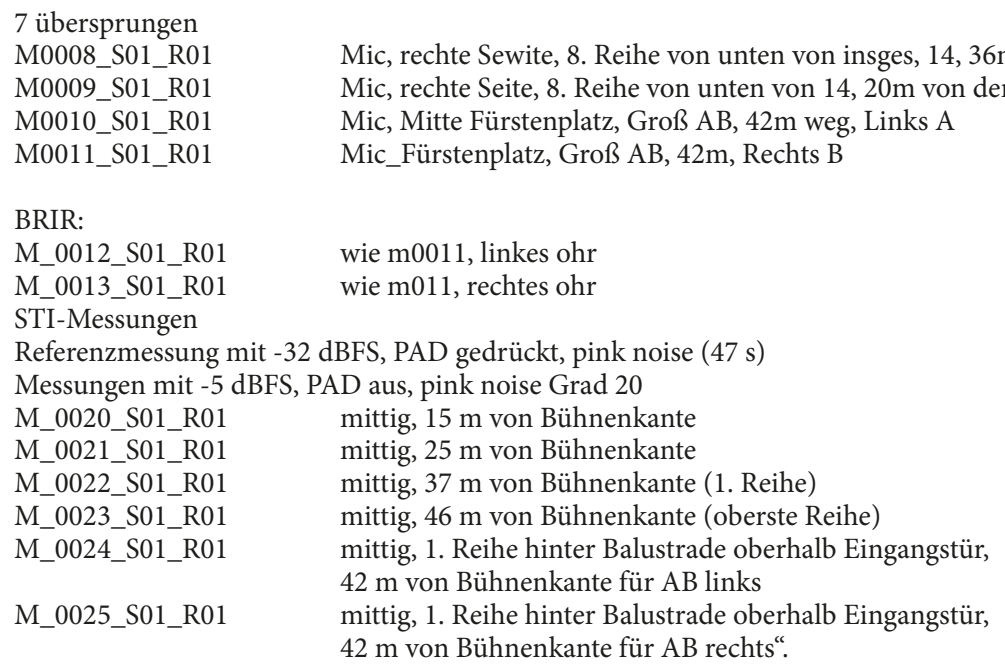

1. The Salone dei Cinquecento in the Palazzo Vecchio in Florence is a famous opera performance space. However, the measurements are difficult to evaluate due to the acoustic inadequacy of the room. The Salone has been already hastily installed in 1494 during the Savonarola Republic as an assembly room of the Consiglio Maggiore within a medieval building.

2. The highly praised Teatro "Scientifico" of Mantua by Antonio Bibiena (1768) more precisely denominated Teatro dell'Accademia dei Timidi in Mantua. Here the heritage of the Bibiena family is evident, especially the legacy of Ferdinando, Antonio's father, with his multiplication of the perspective axes in vertiginous stage concepts. Formerly active in Vienna, Antonio was also responsible, as early as 1755, for the renovations of the famous Florentine Theatre, della Pergola, by Ferdinando Tacca, who had completed the original stage of the building a century earlier, in 1656.

\section{The core investigations of the project}

The "Audio communication team" has performed the evaluation and processing of the measurement results of the following interior spaces over several years:

A. the Mantuan Teatro "Scientifico";

B. the Teatro Farnese in Parma.

The archived measurement results must be analyzed using related historical data. In the process, recordings of historically documented performances, respectively of their texts or musical scores, can be made for both houses in the anechoic chamber of the Audio Communication Department, in its lab called "Akustikprüfstelle", Acoustics test centre, just like it has been done with the measurements from the Teatro Olimpico. These can then be used as source materials for an auralisation process by using a digital geometric model: this is a process invented to model and simulate the experience of acoustic phenomena rendered as a soundfield within a digital space. The procedure is useful for configuring the soundscape of architectural struc- 
tures, concert venues, and public spaces, as well as in making coherent sound environments within virtual immersion systems. An auralisation process did not take place yet in particular in the Mantuan example, but in Parma.

\section{The method. delving into the historical context in order to explain acoustical facts}

The novelty of the project was its combination of sources, technological as well as humanitarian sciences. The historical background of a building was of central relevance for the final evaluation.

For example, it was relevant in Vicenza, where the so-called Accademia Olimpica was founded in 1555, conceived with the main purpose of promoting scientific and theatrical activities. After having organized several theatrical representations already in the 1550s and 1560s, finally the academy in 1580 assigned one of its founding members, the architect Andrea Palladio (1508-1580), with the definitive design of a permanent theatre, integrated into a larger mediaeval complex of buildings, which originally contained among others Vicenza's former dungeons, the so-called Palazzo del Territorio.

In the concept for the Teatro Olimpico, Palladio could draw upon his thorough investigation of the remains of Roman theatres in Italy and of their building techniques. During a series of journeys throughout the Italian peninsula and Istria since 1541, he was concerned with several, partially well preserved, ancient theatres. This is documented in his plans of the theatres in Verona, in Berga (a location in Vicenza) and of the Colosseum and the Baths of Caracalla in Rome, which he both considered as theatrical spaces. He had also studied partially or fully preserved amphitheatres such as Amphitheatrum Castrense in Rome, the Arenae of Pula and Pozzuoli, the amphitheatre of Zagarolo, and the Theatre of Marcellus in Rome. When, in 1556, the Paduan professor of philosophy and amateur architect Daniele Barbaro (1514-1570) edited and annotated the Italian edition of Vitruvius' Ten Books of Architecture, the only architectural source of classical antiquity, all its illustrations were provided by Palladio, including the ground and elevation plan of an ideal Roman theatre - interpreting Vitruvius' textual description.

\section{Methods of simulation and analysis of the reverberance absorption}

For all the analyzed major representative musical theatre houses, an omnidirectional source was placed on stage at a height of $1.7 \mathrm{~m}$ and listener positions were inserted corresponding to the microphone positions of the actual measurements in the theaters at a height of $1.2 \mathrm{~m}$. The absorption coefficients used for the simulation were defined according to observations in the actual theaters. Different absorption coefficients were assigned to the stage and backstage floor, the unoccupied tiers, and the audience, while all other surfaces were treated with a residual absorption coefficient. The latter was fitted so that the simulated reverberation times in the unoccupied theaters would match the measured values within $\pm 5 \%$. All materials used in the building and their corresponding absorption coefficients are shown in the following Table I.

Absorption is just indispensable for a good acoustics. Long reverberances (for example echo effects) can be avoided by absorbing them, in some cases they need to be absorbed in order to assure the intelligibility of all sound. 
Table I. Absorption coefficients used for the simulation of the occupied theatre - i.e. with audience - according to the conventional room acoustics absorption coefficients of the German Metrological Institute of the Federal Physikalisch-technische Bundesanstalt ${ }^{6}$

Different values were used for the stage and backstage floor (2), for the unoccupied tiers (3), for the audience steps (4). The residual absorption, used for sidewalls and ceiling, was fitted so that simulated and measured reverberation times in the unoccupied theatre would match (1). Scattering coefficients were used increasing from 0.3 [seconds] at $125 \mathrm{Herz}$ to $0.7 \mathrm{~s}$ at $8 \mathrm{kHz}$.

\begin{tabular}{|l|l|c|c|c|c|c|c|c|}
\hline & Material & $\mathbf{1 2 5} \mathbf{~ H z}$ & $\mathbf{2 5 0} \mathbf{~ H z}$ & $\mathbf{5 0 0} \mathbf{~ H z}$ & $\mathbf{1 ~} \mathbf{k H z}$ & $\mathbf{2} \mathbf{~ k H z}$ & $\mathbf{4} \mathbf{~ k H z}$ & $\mathbf{8 ~} \mathbf{~ H z}$ \\
\hline 1 & Residual absorption (plaster layer) & 0.20 s & 0.15 & 0.12 & 0.12 & 0.12 & 0.13 & 0.15 \\
\hline 2 & Parquet floor of [back]stage & 0.15 & 0.11 & 0.10 & 0.07 & 0.06 & 0.07 & 0.07 \\
\hline 3 & Wood, 1“ with air space behind & 0.19 & 0.14 & 0.09 & 0.06 & 0.06 & 0.05 & 0.05 \\
\hline 4 & Audience on wooden chairs & 0.20 & 0.35 & 0.72 & 0.80 & 0.94 & 0.84 & 0.59 \\
\hline
\end{tabular}

The most relevant example: the Farnese theatre - and its genealogical descent in Mantua.

Regarding the Farnese Theatre, Bruno Adorni (State University of Parma), who has done a lot of research on the theatre has given the project his support and studied the numerous constructive changes in the building before (for example, [1]). Although already from 1689 onwards the enormous renovation and extension of this exemplary house had been conceived by Ferdinando Galli Bibiena (1656-1743), there must be in my opinion an eminent line of continuity between it and the Teatro Scientifico in Mantua, realized several decades later (in 1768). The Parmese theatre cultural heritage - or rather the new concept of space introduced there especially for the ambitious local dynasty - was continued without interruption at other hotspots of the European theatre tradition: for example, in Nancy (Fig. 6), Verona (above mentioned), Bayreuth or Mantua. Moreover, the architect Antonio (also Antonio Luigi) Galli Bibiena (1697/8-1774), who was born in Parma and was appointed to Mantua and many other theatre centers, was directly related to the Bibiena family branch which simultaneously continued to work in Parma with success (his own stage projects, drawing R.I.B. A., dated 1751, shelf mark 22227) [7]. Indeed, Parma is where Europe's largest theatre building of the $17^{\text {th }}$ century was indeed located and Antonio had been originally trained by his father Ferdinando there.

In any case, there might be also intermediate exemplary models between Parma and Mantua: like Bologna's Teatro Comunale by Antonio Galli Bibbiena, erected 1756-1763, and maybe even more interesting, in Genoa the Teatro Falcone (last reconstruction 1705), which alas was bombed in WW2.

But let us remain in Mantua: here, however, it was through Antonio that the baroque venue was thoroughly reformulated and modernized by introducing a "bell-shaped" ground plan (Fig. 7). In fact, the concept of the complex shows many innovations compared to contemporary or earlier related buildings (we shall come back to this aspect later).

6 Or PTB. https://www.ptb.de/cms/ptb/fachabteilungen/abt1/fb-16/ag-163/absorption-coefficient-database. html. 


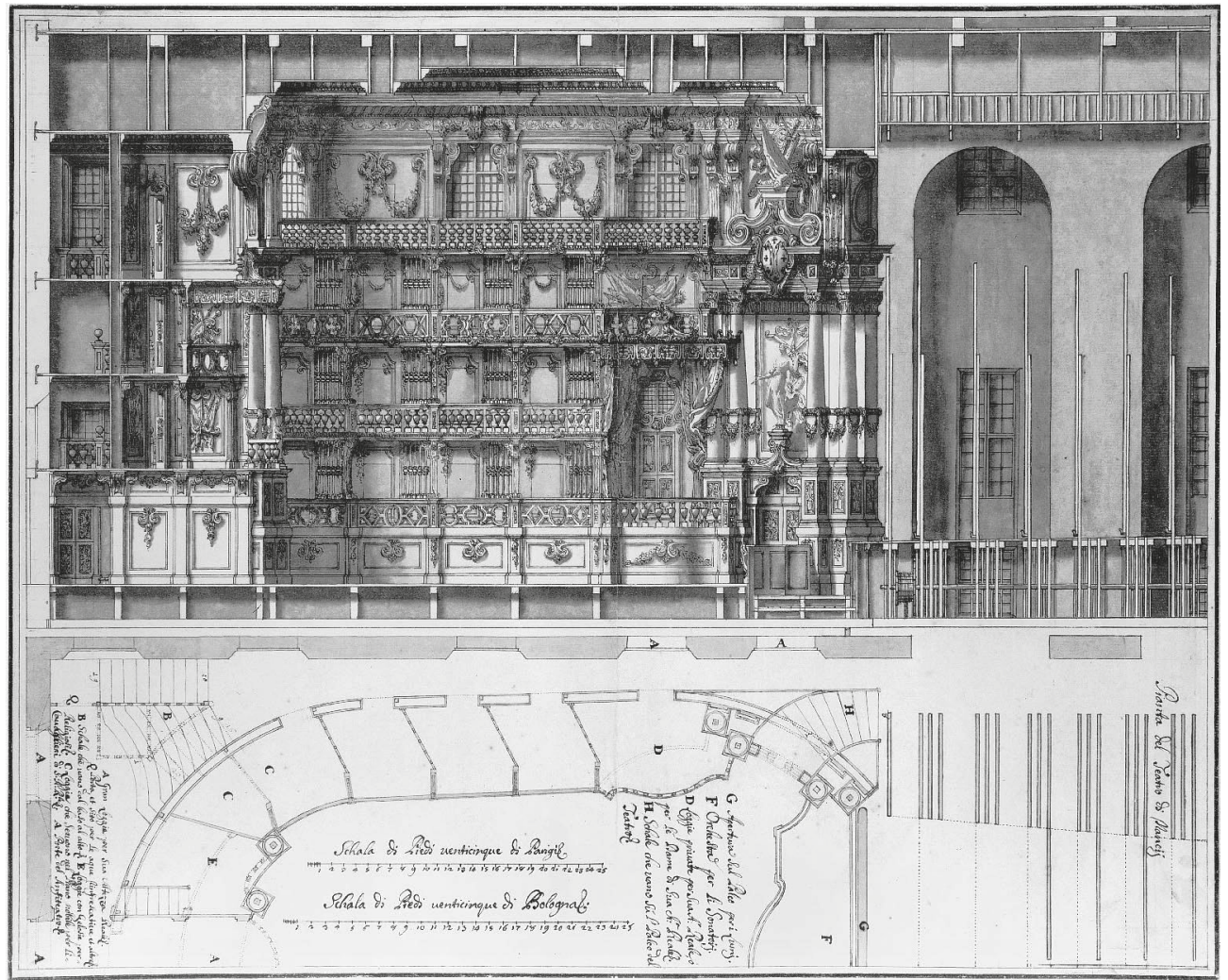

Fig. 6. Nancy, Opera House, drawing by Francesco Galli da Bibiena, 1707-1710. Metropolitan Museum, New York. Available at: https://upload.wikimedia.org/wikipedia/commons/1/13/Designs_for_the_Theater_at_Nancy-_Longitudinal_Section_ and_Half_Ground_Plan_MET_MM52380.jpg

For example, in Giuseppe and Carlo Galli da Bibiena's Markgräfliches Opernhaus in Bayreuth (1744) the innovative features are represented by the adoption of side columns as sound diffusers and by the change of displacement of the perspective focus from the centre of the orchestra (as in the tradition) to the centre of the stage - as it can clearly be recognized from the ground plan. These aspects will all become a reference for the future symphonic hall, characterized by the geometric proportions of the Renaissance shoe-box hall we had already found as early as in 1588 in Sabbioneta, a flat ceiling (that we, however, know from all our examples) and scattering side surfaces, characterized by a wealth of stucco decorations.

Also, in Vicenza, as it is clearly visible on the ground plan, the distance from the orchestra pit to the viewer is, maybe, the shortest ever, even shorter than in any Italian late $17^{\text {th }}$ century example so far considered. The reason of this shortening in depth may surely be the oligarchic society of local receivers, which was way smaller than the one in Mantua or in Parma or in similar important ducal capitals. After all, Vicenza was a minor provincial centre. Still, there is a direct architectural-theoretical genealogy from Mantua to Vicenza. One of the patrons, 


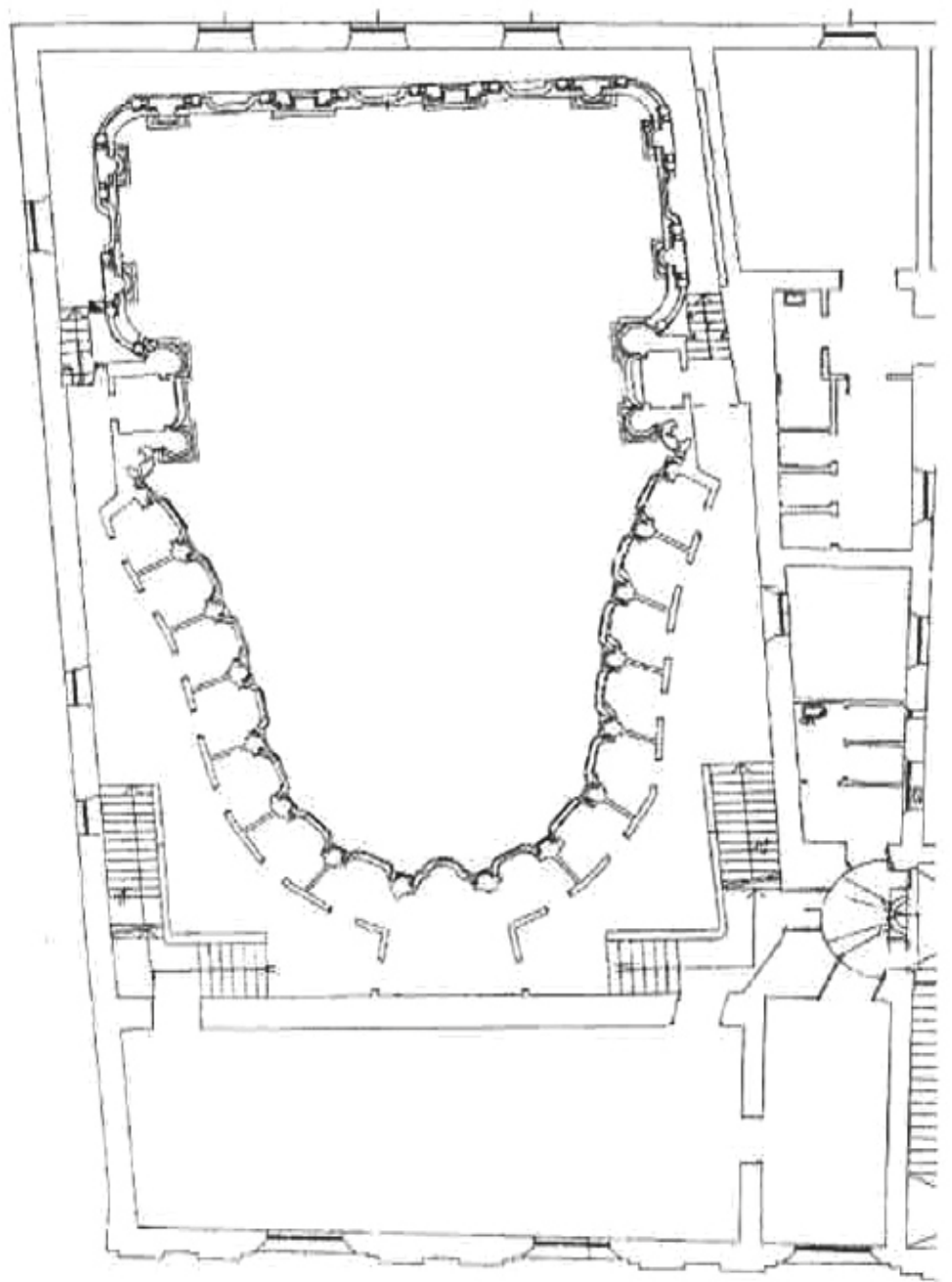

Fig. 7. Mantua, Teatro Scientifico's "bell-shaped” ground plan. Archive Comune di Mantova, Settore opere pubbliche. Photo by P. Sanvito

Graf Carlo Ottavio Colloredo in a letter to Wenzel Anton Fürst Kaunitz openly declared: the Mantuan example should become „un Teatro del genere degli Olimpici“, i. e. along the Palladian example.

Like many other researches before us, we have noticed in Mantua a multiplication and simultaneous differentiation in the use of the stage venue for official representation purposes or ceremonies, partly for academic conferences, and even a restructuring of the adjoining secondary rooms according to performative needs. The consideration of the acoustic point of view from the architect's side has essentially contributed to this feature: not only was this venue 
intended for musical performances, it was also part of the representative buildings of a scholarly academy and therefore served the purpose of scholarly exchange, being also designed for scientific lectures and experiments (therefore named "Scientifico"); or even for solemn festivals and highly political meetings. Some events in Mantua during the Austrian dominion were often of political nature. After all the governors of the province (since 1708 imperial) saw it as an Austrian contribution to the local arts, as it had been built with a contribution of 40.000 Lire granted by Empress Maria Theresia of Habsburg.

\section{Peculiar features of the Mantuan Scientifico}

From the point of view of its project design, the theatre is characterized by an absolutely unheard opening of the stage space towards the outside, which may be related to the academicians' representative purposes, and at the same time it evokes a very peculiar aesthetic.

In first place, the stage is open on its backside, toward the adjacent street from which even fresh air can be let in. A double perimetral wall pierced by three double layered windows can either communicate with the exterior space, or it can be sealed off. The stage surprisingly has a relatively small depth (5,6 m with a shape of ground plan which approximates a double square, the width being $12,3 \mathrm{~m}$ ): this design is presumably not intentional, but due to the condition of the lot of land which was available for construction. But, on the other hand, it assimilates in the Mantuan case the intentional orientation as in Vicenza, directing the sound away from the backdrop and to the front (audience).

The height of the stage is $10,9 \mathrm{~m}$. Sitting thus in the loge hall, no spectator would ever guess that the rear wall of the stage is not a fictitious backdrop, elegant features and complex plaster decoration allows the beholder to assume that it is a multilayered stage design, as was usual in this period with architectural imitations. But the windows are real: if, in case, they get sealed off, possibly with wooden panels, they can assure a good acoustical performance to the entire space, also because the behavior of wooden materials is famously favorable to virtuous acoustics. But sealing them is not compulsory, of course. Francesco Algarotti, an internationally famous and successful theoretician of the musical theatre and the stage, in general, analyses the introduction of a "bell ground plan" in the usage of opera houses plans: in his treatise, Saggio sopra lopera in musica, which enjoyed its second edition just in these same years, he promotes its use and even defines it as a "sophisticated invention" .

The acoustical proficiency in the Scientifico, which was already confirmed before Wolfgang Amadeus Mozart's concert in 1769, was praised in 1768 by the Prefect of Mantova, Carlo di

\footnotetext{
"La bocca della campana corrisponde all'imboccatura della scena e il palchetto di mezzo viene a esser posto colà, donde nella campana è sospeso il battaglio. Quale sia il fondamento di così raffinata invenzione è facile a vedersi: la similitudine cioè o l'analogia, che immaginarono doversi trovare tra il suono reso dalla campana, e la figura della campana che il rende. Ma egli è anche facile a conoscere quale sia di tal fondamento la saldezza. La figura della campana con quelle sue labbra che mettono all'infuori è attissima a spandere per ogni verso il suono del battaglio: che batte in quelle labbra medesime. E sospesa chella sia d'alto, mette facilmente in agitazione il mare d'aria che le è d'intorno. Ma che per ciò? Dovrà la voce del cantore, posto quasi nella bocca della campana del teatro, fare gli stessi effetti nelle interne parti di essa? Ciò potrebbe per avventura trovar fede presso a coloro, che credevano dover correre .... He also notes some inconveniences: "Oltre di che non poche sono le disconvenienze che risultano dalla figura della campana: il venirsi a restringere con essa lo spazio della platea, e il far perdere a parecchi palchetti la veduta di tutta la scena, e alcune altre che qui riferire non giova" ([2] 1755 or 1763 ed., p. 77).
} 
Colloredo (the Mantuan, "bell" ground plan): it was "così felicemente addattato alla musica in ogni riguardo" (so happily adapted to music from any point of view) ${ }^{8}$.

It is obvious that the treatises (as well as the graphic material) on architecture from the Bibiena family legacy, such as the impressive perspectival treatise edited in Parma in 1711 [9], must have played an unmistakable role in Antonio's design idea. Ulla Quecke's dissertation unfortunately does not take into account the graphic or theoretical legacy of this artistic clan.

\section{The archive of data from Mantua}

The material on the Mantuan theatre in the archive of the Audio Communication Team has not yet been integrally evaluated and consists of numerous files. They are the source of information at the same time on average and on relevant physical facts. Among them, there are ten room acoustical impulse responses which can be evaluated with regard to reverberation time and other room acoustic parameters, especially speech intelligibility; and secondly, there are measurements of the space and its single components?.

The measurements are:

a) five "Impulse responses" (RIR) - for evaluation with regard to the reverberation time, absorption, etc.;

b) five "Impulse responses" (STI) for evaluation with regard to the speech intelligibility (specifically: the speech intelligibility index, STI);

c) physical inventory of the surfaces.

Besides, I have already mentioned here the unique proficiency of the theatre interior decoration, which is very sophisticated also in terms of acoustics because of its sound wave absorbing properties, in a similar way as in these same years in Bayreuth.

\section{Final evaluation and conclusions}

The expected result is the evaluation of the possibilities and potentials of the recently analyzed northern Italian theatres as paradigm: comprising those having an undisputed function, proven by the exemplary character they have possessed throughout the centuries for venues created later - especially in the case of the Mantuan example, but not only there. Finally, their importance should not only be perceived in the circle of initiates of acoustics research (or only in those of Italian art-historical research), but also by other researchers in the fields of history and even musicology.

Collecting this material, we verified the Europe-wide relevance of the efforts of "technicising the theatre", observed at least since the renovations and stage extensions in Parma around the late 1680s. In addition, the central questions of the placement of the musicians or of the orchestra (over the almost two hundred years of opera practice in this house) got into the focus. In fact, the Parma orchestra pit with its large size and depth influenced the Bayreuth solution.

Archivio Storico Accademia Nazionale Virgiliana, Mantua, b. 25, f. 3.

An acoustical evaluation is however not available yet. The evaluation provided 2001 by Silvio Torelli (technician of the Mantuan company Audiocostruzioni), published in an article with very inaccurate data on the "Acoustics of the Scientifico", remains largely below the [in our opinion] required scientific level. The author has not published any diagrams of his data in these documents (and perhaps there have never been. See [17]). 
Data analysis: The data grounding meets the requirements to make important statements regarding room acoustics, as well as to create an auralisation of an acoustic stage and an auditorium: the measurements were carried out in all cases in an unoccupied state, while no visitor was allowed to access it. Thus, the novelty of the new planning systems, in the considered examples, can be vividly clarified and demonstrated on the base of technical data. Average data oscillating between 2,4 and 3,3 via 2,8 seconds in all average measurements of the examples confirm that reverberation never became an issue - at least in the Italian area considered here; the scope of revisiting in the musical theatre a repertory of classicizing mythologies and their dramatic action was perfectly fitting to an andamento grave, solemn style, and tempi in sostenuto, which were supported by a longer reverberance than what we are accustomed today.

Table II. Parameters of the Teatro Olimpico in Vicenza for the unoccupied case derived from the measurement $(\mathrm{M})$ and the unoccupied case derived from the simulation (S)

a. $\mathrm{G}_{\mathrm{m}}, \mathrm{EDT}_{\mathrm{m}}$,=in s(econds)., is the early decay time, that is an indicator for a perceived reverberance. C- $80_{\mathrm{m}}$ are average values of the $500-1000 \mathrm{~Hz}$ range. STI values are given only for those receiver positions where measurements had been conducted. Mean values are in red. (R1 through R9 or simply 1-9 are receivers' positions)

\begin{tabular}{|c|c|c|c|c|c|c|c|c|}
\hline & \multicolumn{2}{|c|}{$\mathrm{G}_{\mathrm{m}}(\mathrm{dB})$} & \multicolumn{2}{|c|}{ 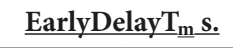 } & \multicolumn{2}{|c|}{$C-80_{m}(d B)$} & \multicolumn{2}{|c|}{ Speech Trans. Index } \\
\hline & $\mathbf{M}$ & S & Unocc. & Occ. & $\mathbf{M}$ & $S$ & $\mathbf{M}$ & $S$ \\
\hline R1 & I & 10.8 & 3.3 & 3.4 & -2.1 & -1.8 & 0.56 & 0.57 \\
\hline R2 & I & 9.6 & $\underline{3.4}$ & 3.4 & -6.2 & -4.9 & I & I \\
\hline R3 & I & 9.4 & 3.5 & 3.3 & -3.1 & -5.2 & 0.49 & 0.45 \\
\hline R4 & I & 10.4 & 3.5 & 3.4 & -3.5 & -2.1 & I & I \\
\hline R5 & I & 9.3 & 3.3 & 3.4 & -3.9 & -4.5 & 0.44 & 0.40 \\
\hline R6 & I & 8.8 & 3.2 & 3.5 & -3.6 & -4.6 & 1 & I \\
\hline R7 & l & 10.3 & 3.4 & 3.3 & -2.6 & -2.2 & I & I \\
\hline $\mathrm{R} 8$ & l & 9.5 & 3.3 & 3.3 & -4.1 & -3.8 & I & I \\
\hline R9 & 1 & 9.2 & 3.3 & 3.3 & -7.3 & -3.6 & $\begin{array}{c}/ \\
\text { mean: } \\
\underline{0.46}\end{array}$ & I \\
\hline
\end{tabular}

b. Parameters of the Teatro Olimpico in Sabbioneta for the unoccupied case derived from the measurement $(\mathrm{M})$ and the unoccupied case derived from the simulation $(\mathrm{S}) . \mathrm{G}_{\mathrm{m}}, \mathrm{EDT}_{\mathrm{m}}, \mathrm{C}-80_{\mathrm{m}}$ are average values of the $500-1000 \mathrm{~Hz}$ range. STI values are given only for those receiver positions where measurements had been conducted.

\begin{tabular}{|c|c|c|c|c|c|c|c|c|}
\hline \multirow{2}{*}{} & \multicolumn{2}{|c|}{$\mathbf{G}_{\mathbf{m}}(\mathbf{d B})$} & \multicolumn{2}{c|}{$\mathbf{E D T}_{\mathbf{m}}(\mathbf{S})$} & \multicolumn{2}{c|}{$\mathbf{C}_{\mathbf{8}} \mathbf{8 0}_{\mathbf{m}}(\mathbf{d B})$} & \multicolumn{2}{c|}{ STI } \\
\cline { 2 - 9 } & $\mathbf{M}$ & $\mathbf{S}$ & $\mathbf{M}$ & $\mathbf{S}$ & $\mathbf{M}$ & $\mathbf{S}$ & $\mathbf{M}$ & $\mathbf{S}$ \\
\hline $\mathrm{R} 1$ & & 14.1 & 2.4 & $\mathbf{2 . 6}$ & -2.5 & -2.0 & 0.53 & $\mathbf{0 . 4 9}$ \\
$\mathrm{R} 2$ & & 13.8 & 2.4 & $\mathbf{2 . 5}$ & -3.0 & -2.0 & $/$ & $/$ \\
$\mathrm{R} 3$ & & 13.2 & 2.4 & $\mathbf{2 . 6}$ & -2.5 & -2.9 & 0.45 & $\mathbf{0 . 4 5}$ \\
$\mathrm{R} 4$ & & 13.1 & 2.4 & $\mathbf{2 . 5}$ & -2.1 & -2.9 & $/$ & $/$ \\
$\mathrm{R} 5$ & & 13.0 & 2.5 & $\mathbf{2 . 6}$ & -2.0 & -2.5 & 0.49 & $\underline{\mathbf{0 . 5 0}}$ \\
$\mathrm{R} 6$ & & 13.0 & 2.6 & $\underline{\mathbf{2 . 5}}$ & -3.4 & -1.8 & 0.51 & $\mathbf{0 . 5 1}$ \\
\hline
\end{tabular}


Table III. Parameters of the Teatro Farnese in Parma for the unoccupied case derived from the measurement $(\mathrm{M})$ and the unoccupied case derived from the simulation $(\mathrm{S}) . \mathrm{G}_{\mathrm{m}}, \mathrm{EDT}_{\mathrm{m}}, \mathrm{C}-\mathrm{80}_{\mathrm{m}}$ are average values of the $500-1000 \mathrm{~Hz}$ range. STI values are given only for those receiver positions where measurements had been conducted

\begin{tabular}{|c|c|c|c|c|c|c|c|c|}
\hline \multirow{2}{*}{} & \multicolumn{2}{|c|}{$\mathrm{G}_{\mathrm{m}}(\mathrm{dB})$} & \multicolumn{2}{c|}{$\mathrm{EDT}_{\mathrm{m}}(\mathrm{S})$} & \multicolumn{2}{c|}{$\mathrm{C}-80_{\mathrm{m}}(\mathrm{dB})$} & \multicolumn{2}{c|}{$\mathrm{STI}$} \\
\cline { 2 - 9 } & $\mathrm{M}$ & $\mathrm{S}$ & $\mathrm{M}$ & $\mathrm{S}$ & $\mathrm{M}$ & $\mathrm{S}$ & $\mathrm{M}$ & $\mathrm{S}$ \\
\hline $\mathrm{R} 1$ & & 3.5 & $\mathbf{3 . 3}$ & 3.3 & -2.0 & -1.2 & $\mathbf{0 . 6 7}$ & $\mathbf{0 . 4 9}$ \\
$\mathrm{R} 2$ & & 3.3 & $\mathbf{3 . 2}$ & 3.1 & -1.4 & -0.3 & $/$ & $/$ \\
$\mathrm{R} 3$ & & 2.0 & $\mathbf{3 . 3}$ & 3.3 & -4.5 & -5.3 & $\mathbf{0 . 5 5}$ & $\mathbf{0 . 3 6}$ \\
$\mathrm{R} 4$ & & 2.9 & $\mathbf{3 . 2}$ & 3.3 & 1.7 & -1.3 & $/$ & $/$ \\
$\mathrm{R} 5$ & & 2.2 & $\underline{\mathbf{2 . 8}}$ & 2.7 & 2.8 & -0.4 & $\mathbf{0 . 5 9}$ & $\mathbf{0 . 4 2}$ \\
$\mathrm{R} 6$ & & 1.9 & $\mathbf{3 . 1}$ & 3.0 & -0.9 & -1.9 & $\underline{\mathbf{0 . 5 3}}$ & $\mathbf{0 . 3 5}$ \\
$\mathrm{R} 7$ & & & $\mathbf{1 . 4}$ & & & & & \\
$\mathrm{R} 8$ & & & $\mathbf{1 . 7 .}$ & & & & & \\
\hline
\end{tabular}

The impact of the architectural typology originally created, and later improved, in Parma and the sophisticated technical solutions that have been developed in this city, the capital of the multiple stages, cannot be overestimated. It is no coincidence that the Farnese was soon considered "il prototipo del moderno teatro europeo", as the Bolognese historian Deanna Lenzi recently pointed out. The Swedish-Pomeranian architect Nicodemus Tessin the Younger saw and described it in his now edited Travel Notes in 1687-1688 even before the renovation. It is not without reason that he described it in his drawing notebook and highlighted it as "erstes den renommierten grossen theater in dess Herzogs palais" (similar to the original orchestra pit as designed by Francesco Guitti for Enzo Bentivoglio ante 1628) [6, pl. 104]. Nicodemus Tessin besides gave an account of Teatro Farnese with an original drawing in Italian containing the accurate detail of the orchestra pit (on Recto of drawing shelf mark 8507, at the Nationalmuseum Stockholm, Tessin-Hårleman Collection) and later he eventually collected information about the neighbouring Parmese theatres. He also recorded several empirical observations on the efficiency of the acoustic performance, which he could not yet confirm on the basis of technical analyses. For what purpose did he? Shortly afterwards he would build the first Swedish teatro "all'italiana" in Drottningholm for the local kings, which was based on such observations and at the same time all technical drawings collected in Parma and still preserved in Swedish libraries today.

\section{References}

1. Adorni B. Progetto per il restauro del Teatro Farnese. I Bibiena, una famiglia europea. Lenzi D.; Bentini J. (eds.). Bologna, Marsilio Publ., 2000, pp. 223-224 (in Italian).

2. Algarotti F. Saggio sopra l'opera in musica, s.l., 1755 or Livorno, Marco Coltellini Publ., 1763. (in Italian).

3. Arnaldi E. Idea di un teatro nelle principali sue parti simile a' teatri antichi all'uso moderno accomodato: con due discorsi, l'uno che versa intorno a' teatri in generale, riguardo solo al coperto della scena esteriore, l'altro intorno al sofitto di quella del Teatro Olimpico di Vicenza, opera dell'insigne Andrea Palladio. Vicenza, Veronese Publ., 1762. (in Italian).

4. Beranek L. L. Music, Acoustics \& Architecture. New York, Wiley Publ., 1962. 586 p. 
5. Bjurström P. Carl Gustaf Tessin och konsten: en konstbok från Nationalmuseum, Stockholm, Rabén \& Sjögren Publ., 1970. 134 p. (in Swedish).

6. Ciancarelli R. Il progetto di una festa barocca: Alle origini del teatro Farnese di Parma (1618-1629). Roma, Bulzone Publ., 1987. 279 p. (in Italian).

7. Collier W. Rediscovered Theatre Drawings by Antonio Bibiena. Apollo, iss. 86, 1967, pp. 108-111.

8. D’Alberto L. Antonio Galli Bibbiena e il teatro dell'Accademia di Mantova nel quadro delle ricerche di rinnovamento degli organismi teatrali svoltesi nei secoli XVII e XVIII. Civiltà mantovana, iss. 5, 1971, pp. 369390 (in Italian).

9. Galli Bibiena F. L’architettura civile preparata sú la geometria, e ridotta alle prospettive. Parma, Paolo Monti Publ., 1711. (in Italian).

10. Laine M. et al (eds.). Nicodemus Tessin the Younger, Royal Architect and Visionary, vol. 3. Travel Notes 167377 and 1687-88. Stockholm, National Museum Publ., 2002. 459 p.

11. Lenzi D. L'arte del Settecento emiliano; architettura, scenografia, pittura di paesaggio. Matteucci Armandi A. M.; Lenzi D. (eds.). X Biennale d'Arte Antica: l' arte del Settecento emiliano; architettura, scenografia, pittura di paesaggio. Bologna, Edizioni Alfa Publ., 1979 (1980), pp.71-96 (in Italian).

12. Lo Prete L. Enea Arnaldi teorico ed architetto. Arte veneta, iss. 23, 1969 (1970), pp. 181-191 (in Italian).

13. Quecke U. Das Teatro Scientifico in Mantua: Architektur und Funktion eines oberitalienischen Akademietheaters des 18. Jahrhunderts. Frankfurt am Main, Lang Publ., 1997. 303 p. (in German).

14. Rothgordt K. Il Teatro Accademico del Bibbiena in Mantova. Mantova, Stamperia Citem Publ., 1972. 38 p. (in Italian).

15. Sanvito P. Die Akustik des Teatro Olimpico in Vicenza. Fortschritte der Akustik: DAGA 2011 (37. Jahrestagung für Akustik). Düsseldorf, DAGA Publ., 2011, pp. 33-35(in Italian).

16. Sanvito P. Il Teatro Olimpico di Vicenza. La genesi di un'impresa architettonica e l'Accademia sua fondatrice. Napoli, Paparo Edizioni, 2012. 110 p. (in Italian).

17. Sanvito P.; Weinzierl S.; Schulz F. L'acustica del Teatro Olimpico. Odeo Olimpico (Vicenza), 2013, pp.463492 (in Italian).

18. Sanvito P. Francesco di Giorgio, Constructing Acoustical Spaces. Pegasus (Berlin), iss. 17, 2015, pp. 9-32.

19. Sanvito P.; Weinzierl S.; Schulz F. The Acoustics of Renaissance Theatres in Italy: Vicenza, Sabbioneta, Parma. Acta Acustica united with Acustica, iss. 101, 2015, pp. 632-643.

20. Sanvito P. Theatre Theory and Acoustics in Sabbioneta. The Invention of an Experimental Architectural Typology. Barbieri F.; Sanvito P. (eds.). Scamozzi teorico europeo. L'opera dell'ultimo dei vitruviani tra Italia, Polonia e Inghilterra. Vicenza, edizioni dell'Accademia Olimpica Publ., 2016, pp. 54-78.

21. Sanvito P. Der Stellenwert des Parmenser Theaters Farnese in der Geschichte des höfischen Musiktheaters und in der Geschichte der Akustik. Musiktheater im höfischen Raum. Heidelberg, Heidelberg University Publ., 2019, pp. 199-228 (in German).

22. Togliani C. Il teatro ducale di Sabbioneta. Zuccoli N. (ed.). Teatri storici nel territorio mantovano, forme, significato, funzioni. Mantova, G. Arcari Publ., 2005, pp.61-80 (in Italian).

23. Torelli S. Le caratteristiche acustiche del Teatro "Scientifico" di Antonio Galli Bibiena in Mantova. Civiltà mantovana, series 3, iss. 36, 2001, pp. 112, 114-131 (in Italian).

24. Weinzierl S. Handbuch der Audiotechnik. Berlin, Springer Publ., 2008. 1205 p. (in German).

Title. Progress of Spatial Acoustics in the Northern Italian Theatres and Stage Architecture during the Baroque Era

Author. Sanvito, Paolo - Ph. D., Dr. Habil. Arch, associate professor. Austrian Academy of Sciences, Institute for Habsburg and Balkan Studies, Research Unit History of Art "Visual Arts as Psychagogic Media of the Jesuits”, Hollandstraße 11-13, 1020 Vienna, Austria. sanvito@win.tu-berlin.de ORCID: 0000-0002-5767-9806

Abstract. Until a few years ago, the architectural history of the Renaissance only sporadically addressed the problem of sound regulation and optimisation inside closed spaces (in German technically: Raumakustik). Instead, nowadays we are currently experiencing a flood of publications about some of the greatest European stage architects, such as Scamozzi, or the Bibiena architectural dynasty: in both cases very famous architects, to whom several symposia and exhibitions have quite recently been dedicated. Nevertheless, there have unfortunately been only isolated references to their views on the subject of theatre acoustics and very scarce research on their bequests in the field. That is why, for about a decade now and especially in Germany, where some of Europe's leading acoustics researchers are based and where the most lively debates on concert halls have been taking place, some core questions had to decisively get addressed. First, what level of acoustics the 
buildings of the ancien régime have generally been reaching; and Second, what were the ways to achieve good acoustics in architecture from the early modern period to the classical period (e. g. with Haydn) and through the Romantic era. The author has been working for several years, together with numerous colleagues, primarily of the Technical University Berlin, on questions concerning the understanding of sophisticated acoustics in performance spaces. The "Audiokommunikation" team in Berlin has most recently performed the evaluation and processing of the measurement results of the the Teatro "Scientifico" in Mantua and the Teatro degli Antichi in Sabbioneta. The archived measurement results are to be analyzed using related historical data. In the process, recordings of historically documented performances can be made for both houses in the anechoic chamber of the Audio Communication Department.

Keywords: spatial acoustics, Bibiena, Palladio, stage architecture, Baroque theatre

Название статьи. Развитие пространственной акустики в театрах Северной Италии и сценическая архитектура в эпоху барокко

Сведения об авторе. Санвито Паоло - Ph. D., Dr. Habil. Arch, доцент. Австрийская академия наук, Институт исследований Габсбургской монархии и Балкан, Hollandstraße 11-13, 1020 Вена, Австрия. sanvito@win.tu-berlin.de ORCID: 0000-0002-5767-9806

Аннотация. До последних лет исследования, посвящённые итальянской архитектуре Ренессанса, лишь эпизодически обращались к проблеме акустики в замкнутых пространствах. Вместо этого, в настоящее время мы наблюдаем поток публикаций о некоторых наиболее известных театральных архитекторах Европы, таких как Скамоцци или Бибиена, которым недавно были посвящены ряд выставок и симпозиумов. К сожалению, взгляд архитекторов на проблему театральной акустики и их достижения в этой области были удостоены лишь отдельных упоминаний и поверхностных исследований. Вот почему уже около десяти лет в Германии, где базируются некоторые ведущие европейские исследователи акустики и ведутся оживленные дебаты о театральной архитектуре, необходимо было дать убедительный ответ на ряд ключевых вопросов. Во-первых, какого уровня акустики в целом достигали античные здания; во-вторых, каковы были способы достижения хорошей акустики в архитектуре от Раннего Нового времени до классического периода и, далее, в эпоху романтизма. Автор работы уже несколько лет работает вместе с многочисленными коллегами (в первую очередь из Технического университета Берлина) над вопросами, касающимися изучения сложной акустики в театральных пространствах. Команда «Аудиокоммуникация (Audiokommunikation)» в Берлине недавно выполнила оценку и работает над обработкой результатов измерений в театре Бибиена в Мантуе и в театре Олимпико в Саббионете. Полученные результаты должны быть проанализированы с использованием соответствующих исторических данных. Записи исторически документированных выступлений могут быть сделаны в безэховой комнате Отдела аудиосвязи.

Ключевые слова: пространственная акустика, Бибиена, Палладио, сценическая архитектура, театр барокко 